\title{
PROCJENA OPSEGA POPLAVE DALJINSKIM ISTRAŽIVANJIMA
}

\section{FLOOD EXTENT ESTIMATION USING REMOTE SENSING}

\author{
Tea Butković ${ }^{*}$ Andrea Maretić ${ }^{* *}$, Bojana Horvat $^{* * *}$, Nino \\ Krvavica $^{* * *}$
}

\begin{abstract}
Sažetak
U radu su, na primjeru poplave koja je u svibnju 2014. godine zadesila istočnu Hrvatsku, uspoređene tri metode kartiranja i procjene opsega poplavljenog područja: metoda analize refleksije s površine u blisko infracrvenom (IC) dijelu spektra (jednokanalna metoda) te metode vegetacijskog indeksa NDVI (Normalized Difference Vegetation Index) $i$ vodenog indeksa NDWI (Normalized Difference Water Index). Metode kao ulazne podatke koriste snimke snimljene pasivnim senzorom ugrađenim na satelitsku platformu Landsat 8. Analizirane su četiri snimke; snimljene su prije (jedna snimka), tijekom (jedna snimka) i nakon poplave (dvije snimke). Procjena temeljena na jednokanalnoj metodi rezultirala je površinom manjom od površina procijenjenih primjenom višekanalnim metodama. Rezultati se mogu objasniti kompleksnošću spektralnog potpisa plitkih poplavnih voda $s$ visokim udjelom suspendiranog nanosa koji će utjecati na refleksiju takvih površina u blisko IC dijelu spektra i klasificirati ih kao nevodene površine. S druge strane, kombiniranjem različitih spektralnih kanala u višekanalnim metodama kompenzira se utjecaj suspendiranog nanosa na refleksiju takvih voda te je klasifikacija na vodene i nevodene površine preciznija.
\end{abstract}

Ključne riječi: poplave, daljinska istraživanja, kartiranje, Landsat 8, NDVI, NDWI

\footnotetext{
* Instruktor project Rovinj, d.o.o., Zagrebačka 5, 52210 Rovinj E-mail: tea.butkovic@gmail.com

** GP Krk, d.d., Stjepana Radića 31, 515000 Krk E-mail: andrea.maretic@gmail.hr

***Sveučilište u Rijeci, Građevinski fakultet, Radmile Matejčić 3, 51000 Rijeka E-mail: \{bojana.horvat, nino.krvavica\}@gradri.uniri.
} 


\begin{abstract}
Using the example of flood in eastern Croatia in May 2014, the paper compares three flood mapping methods: reflection in near infrared (IR) interval of the electromagnetic spectrum (EMS) (one band method), and two multiband methods, namely Normalized Difference Vegetation Index (NDVI) and Normalized Difference Water Index (NDWI). Input data for all three methods are satellite images recorded with the sensor carried by the Landsat 8 satellite. Four data sets were analysed: one recorded before the event, one during the flood and two images recorded after the event. Estimation based on the one band method resulted in the area smaller than the area estimated using the multiband methods. Such results may be explained with the complexity of the spectral signature of the shallow flood waters containing suspended load, which alters the near IR reflection from water surfaces and classifies them as non-water surfaces. Combining the various spectral bands in the multiband methods that impact is compensated and classification of water and non-water surfaces is more precise.
\end{abstract}

Key words: proceedings, instructions, layout, camera-ready manuscript

\title{
1. Uvod
}

Poplava je privremena prekrivenost vodom područja koje inače nije prekriveno vodom. Posljedica je prirodnih procesa i/ili antropogenih aktivnosti: to se odnosi na poplave rijeka, bujičnih vodotoka, plavljenje mora u priobalnim područjima ili izlijevanje vode iz sustava odvodnje. U usporedbi s drugim prirodnim nepogodama, poplave pogađaju najveći dio stanovništva i uzrokuju teške društveno-ekonomske posljedice, humanitarne i ekološke katastrofe. U razdoblju 2009.-2019. poplave su odnijele gotovo 55.000 života i pogodile oko 103 milijuna ljudi te uzrokovale oko $\$ 76,8$ milijardi materijalne štete [1]. Globalno, poplave i ekstremne kiše su se tijekom posljednjeg desetljeća povećale za više od $50 \%$ [2] [3]. Shodno tome, očekuje se da će se kao posljedica združenog djelovanja klimatskih promjena i drugih pritisaka na vodne resurse, poput porasta stanovništva, povećane potražnje za vodom, promjene korištenja zemljišta i sl., negativne posljedice poplava znatno povećati [4].

Kartiranje poplava nezaobilazan je element učinkovitog upravljanja poplavama, odnosno upravljanja kriznom situacijom i planiranja smanjenja/ublažavanja posljedica poplava. Riječ je o procesu određivanja površina zahvaćenih poplavom, procjene opasnosti od pojave poplava, odnosno vjerojatnosti pojave poplavnih događaja te procjene razina poplavnih rizika. Rezultat su pregledne karte poplavljenih područja, karte šteta uslijed poplavnog događaja s dodatnim informacijama (npr. korištenje zemljišta) te karte opasnosti i rizika od poplava [5]. 
Samo kartiranje zahtjevan je zadatak, prvenstveno zbog nedostatka izmjerenih podataka. U tom smislu, daljinska istraživanja su nezamjenjiv izvor podataka, posebno u teško dostupnim područjima. Prednosti korištenja snimaka snimljenih nekim od daljinskih senzora u kartiranju poplava očituju se u dostupnosti podataka o opsegu analizirane poplave te relativno niskoj cijeni njihove primjene budući da su neke snimke dostupne bez novčane naknade [6] (npr. Landsat, Sentinel). Metode izdvajanja vodenih površina na snimkama temelje se na jedinstvenim spektralnim karakteristikama vode koje ju razlikuju od okolnih površina.

\section{Poplavni događaj}

Uslijed višednevnih obilnih oborina u periodu od 13. do 15. svibnja 2014. i probijanja savskih nasipa u blizini Rajevog Sela i Račinovaca (Slika 1), Istočnu Slavoniju je zadesila velika poplava. Na mjesečnoj razini, u mjesecu svibnju 2014. godine na postaji Karlovac zabilježeno je 154,7 mm oborine, u Sisku 193 mm, u Slavonskom Brodu 134,1 mm, a u Osijeku 161,4 mm [7]. U usporedbi s višegodišnjim prosjekom (1961.-1990.), te su mjesečne oborine iznosile $165 \%$ višegodišnjeg prosjeka na postaji u Karlovcu, 236 \% u Sisku, 183 \% u Slavonskom Brodu i 272 \% u Osijeku [8]. Shodno tome, oborinske prilike u središnjoj i istočnoj Hrvatskoj za svibanj 2014. godine opisane su kao ekstremno kišne na širem području Osijeka, vrlo kišne na dijelu istočne Hrvatske te kišne na dijelu središnje i istočne Hrvatske. Tisuće stanovnika evakuirano je iz svojih domova, a materijalna

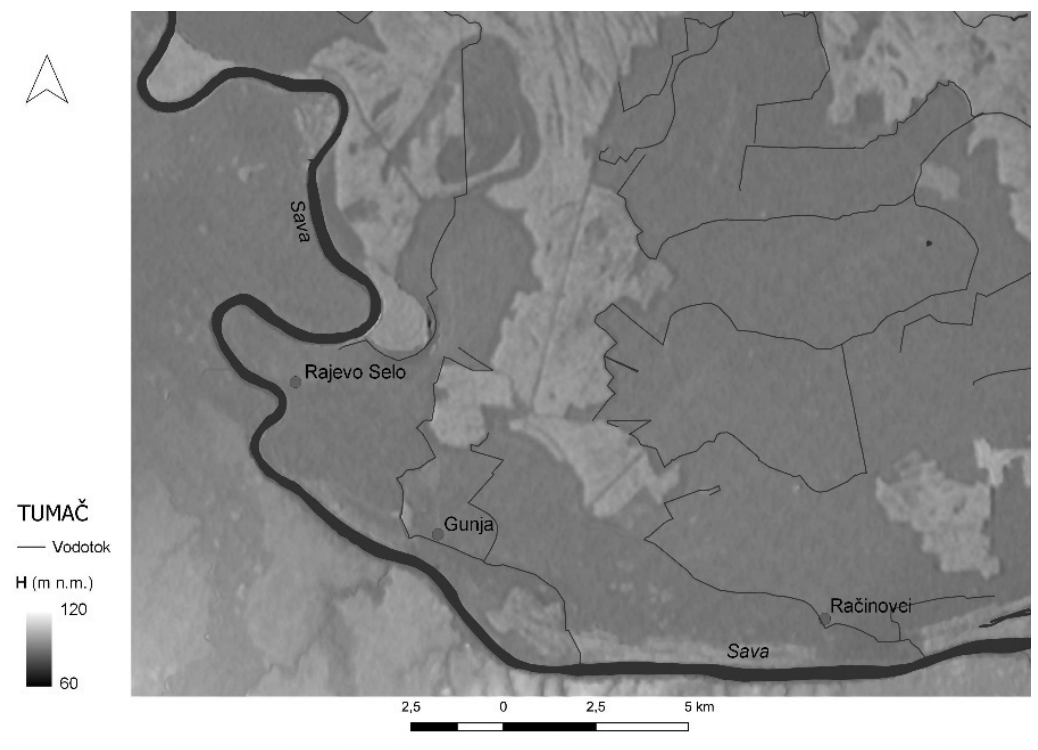

Slika 1. Analizirano područje 
šteta procijenjena je na više od dvije milijarde kuna. Količine oborina u svibnju su nadmašile višegodišnji prosjek na većini analiziranih postaja [9], što je dovelo do pojave ekstremnih protoka u rijeci Savi nizvodno od Slavonskog Boda. Prema podacima Državnog hidrometeorološkog zavoda 17. svibnja je na Savi kod Slavonskog Broda oko $18 \mathrm{~h}$ izmjeren protok od $6007 \mathrm{~m}^{3} / \mathrm{s}$. Taj je protok višestruko nadmašio dotadašnji maksimalni protok Save izmjeren kod Županje 19. siječnja 1970. godine, a koji je iznosio $4161 \mathrm{~m}^{3} / \mathrm{s}$ [10]. Statistička obrada podataka pokazala je da se radi o protoku 1000-godišnjeg povratnog perioda [9]. Osim Istočne Slavonije, poplave su zahvatile i susjedne Bosnu i Hercegovinu te Srbiju.

\subsection{Podaci}

Za procjenu obuhvata poplave, odnosno veličine poplave na analiziranom području korištene su četiri satelitske snimke (Slika 2) snimljene neposredno prije (6. svibnja 2014.), tijekom (22. svibnja 2014.) i nakon poplave (7. lipnja 2014., 13. listopada 2014.) instrumentom OLI (engl. Operational Land Imager), ugrađenom na satelitsku platformu Landsat 8 (Tablica 1).

a)

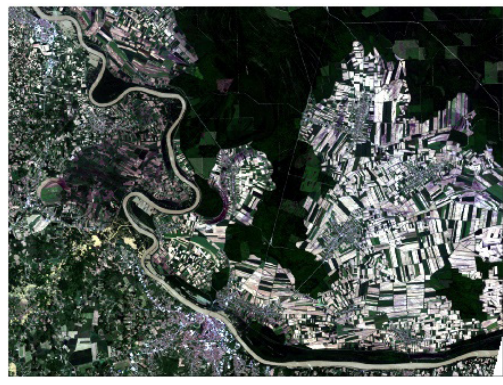

c)

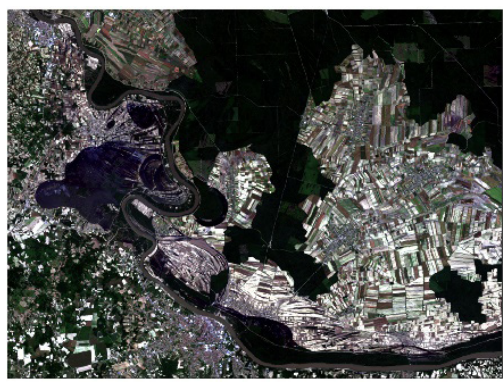

b)

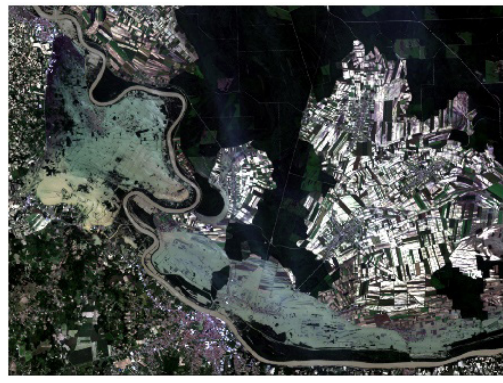

d)

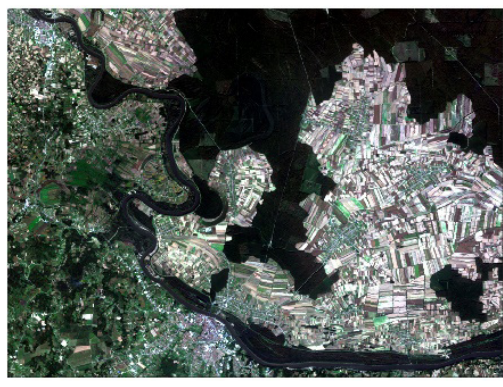

Slika 2. Prirodni kolor kompozit analiziranih Landsat 8 snimaka: a) prije poplave 6. svibnja 2014.; b) tijekom poplave 22. svibnja 2014.; c) nakon poplave 7. lipnja 2014.;

d) nakon poplave13. listopada 2014. 
Tablica 1. Karakteristike Landsat 8 OLI instrumenta [11]

\begin{tabular}{|c|c|c|c|}
\hline \multirow{2}{*}{ Kanal } & $\begin{array}{c}\text { Spektralni interval } \\
(\mu \mathrm{m})\end{array}$ & $\begin{array}{c}\text { Nominalna } \\
\text { spektralna lokacija }\end{array}$ & $\begin{array}{c}\text { Prostorna rezolucija } \\
(\mathrm{m})\end{array}$ \\
\hline B1 & $0,43-0,45$ & & 30 \\
\hline B2 & $0,45-0,51$ & \multirow{2}{*}{$\begin{array}{c}\text { vidljivi (plavi, } \\
\text { zeleni, crveni) }\end{array}$} & 30 \\
\cline { 1 - 1 } B3 & $0,53-0,59$ & & 30 \\
\hline B4 & $0,64-0,67$ & blisko IC* & 30 \\
\hline B5 & $0,85-0,88$ & kratkovalni IC* & 30 \\
\hline B6 & $1,57-1,65$ & kratkovalni IC* & 30 \\
\hline B7 & $2,11-2,29$ & pankromatski & 30 \\
\hline B8 & $0,50-0,68$ & cirrus & 15 \\
\hline B9 & $1,36-1,38$ & & 30 \\
\hline
\end{tabular}

*IC: infracrveni

\section{Metodologija}

Da bi se odredila granica poplavljene površine, primijenjene su i uspoređene tri metode izdvajanja površine na temelju spektralnih karakteristika analizirane površine. Općenito, primijenjene metode se mogu podijeliti u dvije kategorije: (i) metode koje koriste samo jedan kanal (tzv. jednokanalni pristup) te metode koje za klasifikaciju na vodene i nevodene površine koriste informacije izvedene iz više kanala satelitske snimke (tzv. višekanalne metode) [12].

\subsection{Jednokanalna metoda}

Kod ove se metode odabire jedan kanal u kojem se, na temelju specifičnosti reflektivnih karakteristika vode u odnosu na okolne površine, najpreciznije može odrediti granica vodene površine. Granica se određuje vizualnom analizom histograma tog kanala, a zbog subjektivnosti pristupa, metoda nerijetko rezultira podcijenjenom ili precijenjenom veličinom površine.

\subsection{Višekanalne metode}

Razlika između vodenih i nevodenih površina određena je klasifikacijom dva indeksa: normaliziranog vegetacijskog indeksa NDVI (engl. Normalized Difference Vegetation Index) te normaliziranog vodenog indeksa NDWI (engl. Normalized Difference Water Index). Oba indeksa se temelje na specifičnostima spektralnih karakteristika vode i kopnenih površina (vegetacija, golo tlo i dr.), odnosno na reflektivnim karakteristikama pojedinih valnih duljina tih površina (Slika 3). 
Vegetacijski indeks NDVI je jednostavan indikator zdrave vegetacije na promatranoj površini, a u funkciji je blisko IC i vidljivog (crvenog) zračenja. Satelitskim senzorima moguće je kvantificirati koliki udio fotosintetički aktivnog zračenja apsorbira vegetacija jer je neto fotosinteza direktno povezana s apsorpcijom aktivnog zračenja. Općenito, zdrava vegetacija će apsorbirati većinu vidljivog zračenja, a reflektirati blisko IC zračenje. Rijetka i bolesna vegetacija reflektirat će više vidljivog zračenja, a manje blisko IC dok će golo tlo reflektirati podjednako vidljivo i blizu-IC zračenje [13]. Vrijednost ovog indeksa kreće se u rasponu od -1 do 1: gusta i zdrava vegetacija će imati visoke vrijednosti bliske jedinici dok niske, negativne vrijednosti upućuju na vodene površine. Matematička formulacije ovog indeksa je [14]:

$$
N D V I=\frac{\text { blisko IC-crven } i}{\text { blisko IC+crveni }}
$$

Vodeni indeks NDWI sličan je prethodno opisanom vegetacijskom indeksu, $\mathrm{s}$ tom razlikom da za proračun koristi karakteristike površine $\mathrm{u}$ vidljivom zelenom i blisko IC dijelu spektra [15]:

$$
N D W I=\frac{\text { zeleni-blisko IC }}{\text { zeleni+blisko IC }}
$$

Rezultat indeksa su pozitivne vrijednosti za vodene površine te negativne vrijednosti za sve ostale površine (vegetacija, golo tlo i sl.). Indeks se pokazao kao učinkovit u kartiranju vodenih površina u ruralnim sredinama, no u izgrađenim područjima dodjeljuje pozitivne vrijednosti pojedinim izgrađenim objektima [16], što klasifikaciju može učiniti manje preciznom ako se o tome ne vodi računa.

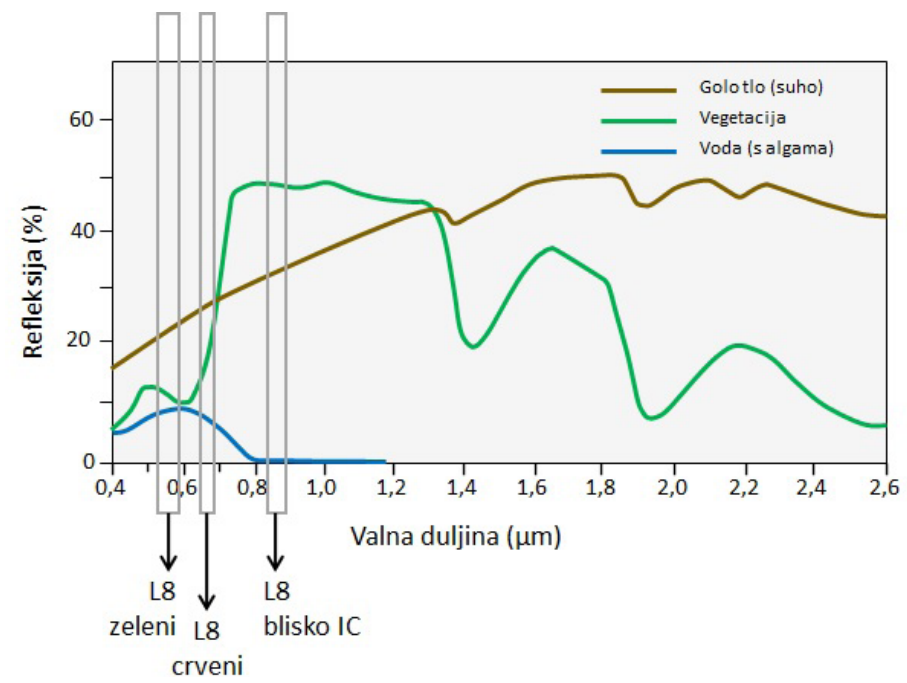

Slika 3. Udio reflektiranog zračenja s karakterističnih površina, s označenim zelenim, crvenim i blisko IC kanalom Landsata 8 (prilagođeno iz [14]) 
Metodološki koraci prikazani su na Slici 4:

1. Jednokanalna metoda:

- Vizualna analiza histograma blisko IC kanala i odabir granične vrijednosti između vodenih i kopnenih piksela

- Klasifikacija snimke

2. Višekanalne metode:

- Izračun indeksa NDVI na analiziranoj površini primjenom jednadžbe (1)

- Klasifikacija snimke s obzirom na NDVI vrijednosti

- Izračun indeksa NDWI na analiziranoj površini primjenom jednadžbe (2)

- Klasifikacija snimke s obzirom na NDWI vrijednosti

3. Usporedba dobivenih rezultata.

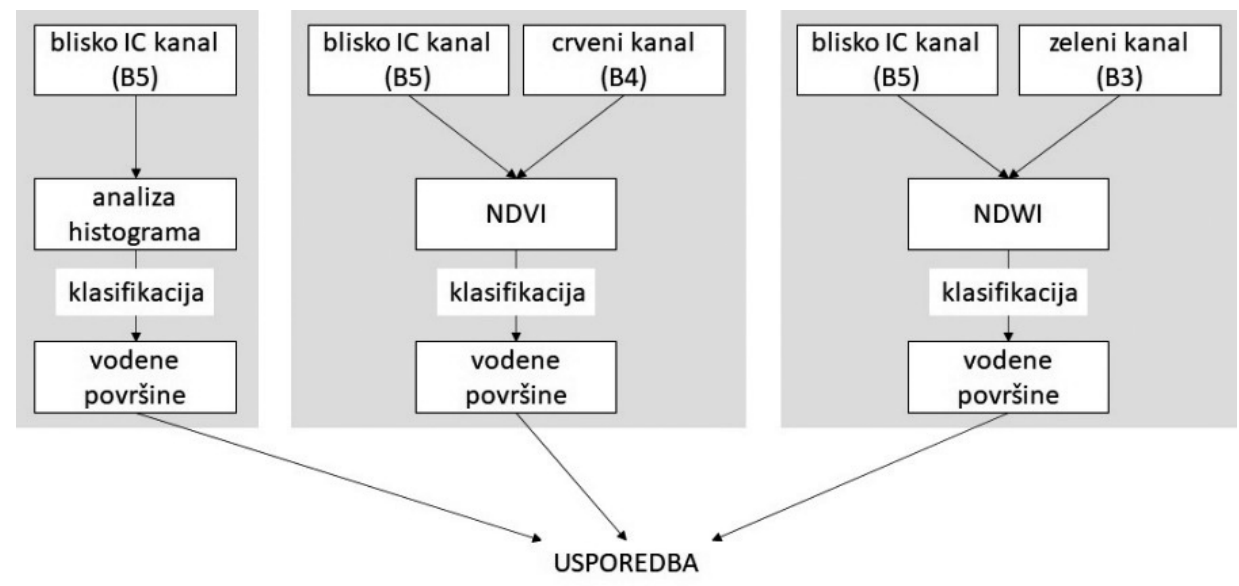

Slika 4. Metodološki koraci

\section{Rezultati i diskusija}

Za klasifikaciju površine jednokanalnom metodom odabran je blisko IC kanal (Landsatov B5 kanal). U bliskom IC spektralnom intervalu (kanal 5 analizirane snimke) voda apsorbira veći dio zračenja tih valnih duljina pa su vodene površine na slici zamjetno tamnije od okolnih površina (Slika 5). Na Slici 5 lijevo prikazano je analizirano područje u blisko IC dijelu spektra. Analizom histograma svake slike (Slika 5 sredina) određena je granica vodenih površina te su na temelju te vrijednosti izdvojene vodene površine (Slika 5 desno). 
a)
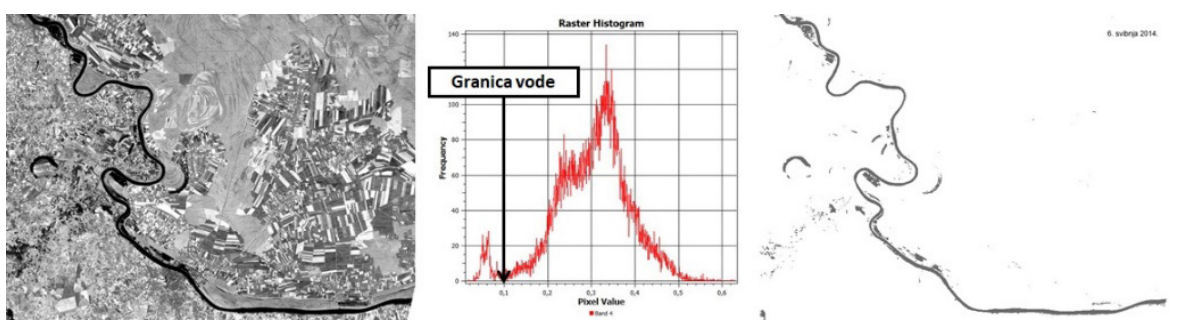

b)
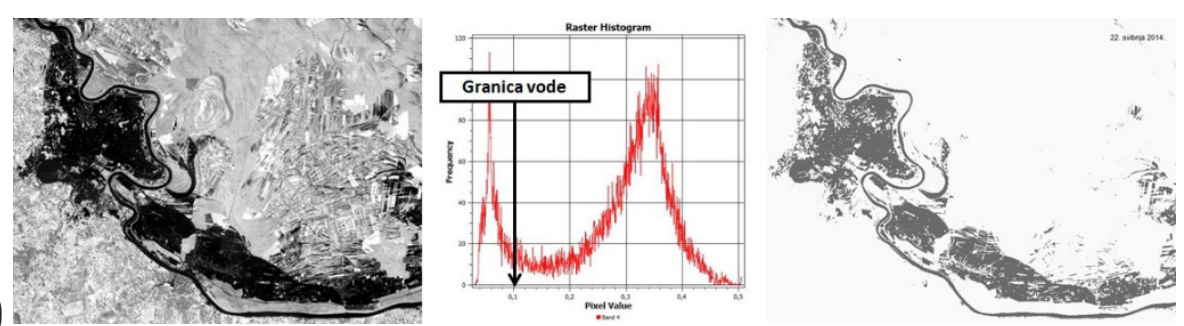

c)
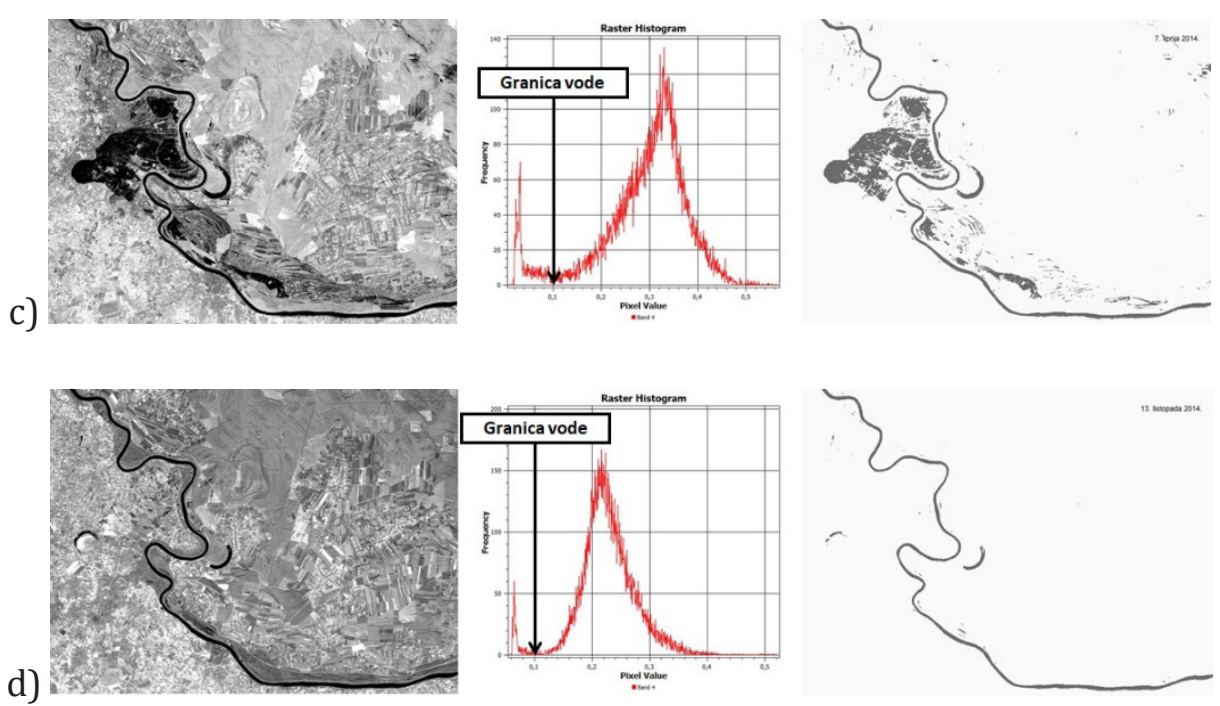

Slika 5. Klasifikacija jednokanalnom metodom: a) 6. svibnja 2014.; b) 22. svibnja 2014.; c) 7. lipnja 2014.; d) 13. listopada 2014.

Primjenom jednadžbe (1) izračunata je prostorna raspodjela vegetacijskog indeksa NDVI (Slika 6 lijevo), a iz dobivenih vrijednosti su izdvojene površine prekrivene vodom na analiziranom području (Slika 6 desno). 
a)
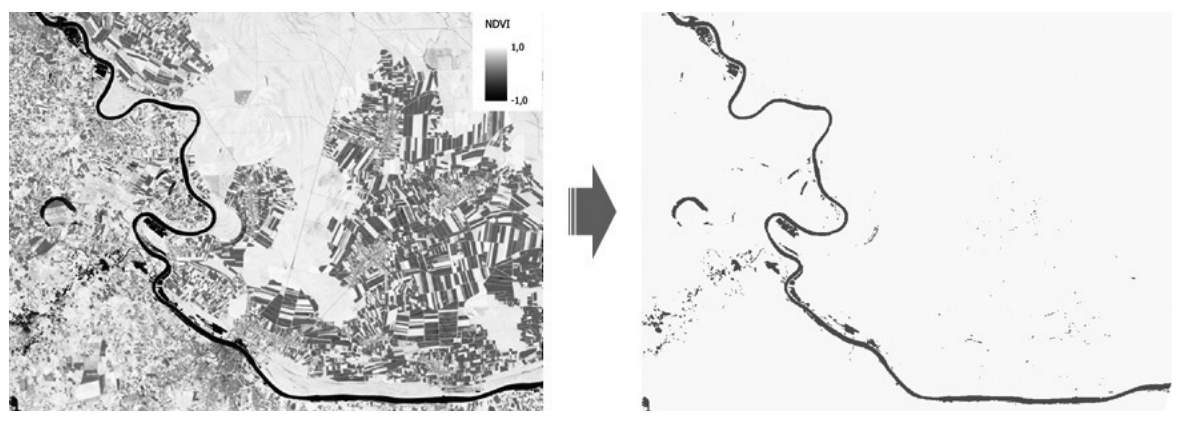

b)
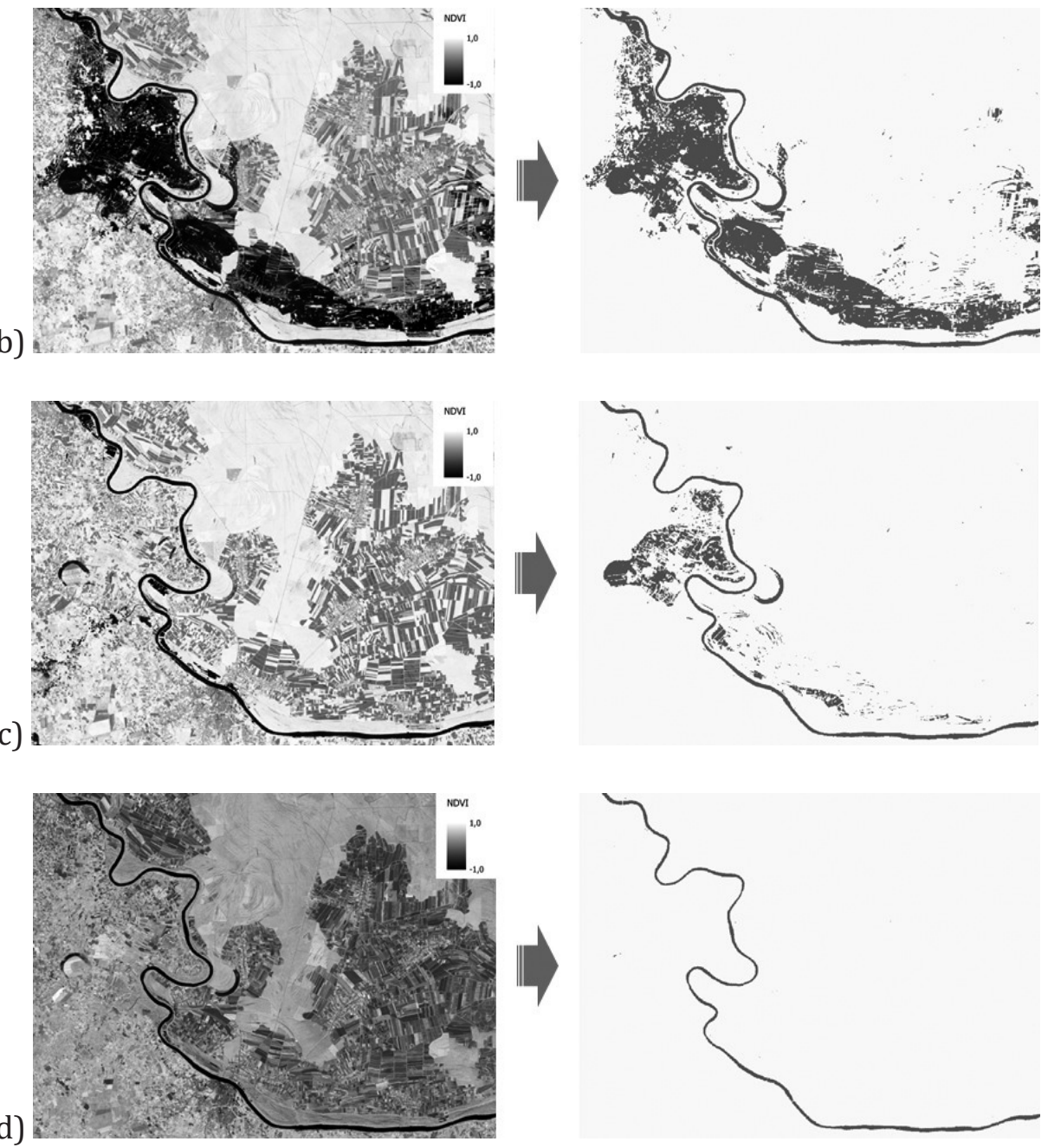

Slika 6. Klasifikacija indeksa NDVI: a) 6. svibnja 2014.; b) 22. svibnja 2014.; c) 7. lipnja 2014.; d) 13. listopada 2014. 
Kao i NDVI, izračunat je vodeni indeks NDWI prema jednadžbi (2) te su dobivene vrijednosti klasificirane na vodene i ne-vodene površine (Slika 7).

Procijenjene veličine poplavljenog područja na temelju podataka prikupljenih daljinskim istraživanjima dane su u Tablici 2. Budući da su na snimci snimljenoj 6. svibnja 2014. zamijećene vodom prekrivene površine (unutar nasipa), analizirana dionica rijeke Save je izdvojena na snimci snimljenoj 13. listopada 2014. kada se voda već potpuno povukla u svoje korito. Kako bi se dobila veličina poplavljene površine, ta je površina oduzeta od ukupne vodene površine detektirane na svakoj snimci.

Tablica 2. Usporedba veličina poplavljenih površina

\begin{tabular}{|c|c|c|c|}
\hline \multirow{3}{*}{ Datum } & Metoda & $\begin{array}{c}\text { Površina } \\
\text { vodotoka } \\
\left(\mathrm{km}^{2}\right)\end{array}$ & $\begin{array}{c}\text { Poplavljena } \\
\text { površina } \\
\left(\mathrm{km}^{2}\right)\end{array}$ \\
\hline \multirow{3}{*}{6.5 .2014}$. & B5 & 11,40 & 6,40 \\
\cline { 2 - 4 } & NDVI & 9,75 & $\mathbf{8 , 6 5}$ \\
\cline { 2 - 4 } & NDWI & 10,88 & 7,77 \\
\hline \multirow{3}{*}{22.5 .2014}$. & B5 & 11,40 & 90,27 \\
\cline { 2 - 4 } & NDVI & 9,75 & 93,35 \\
\cline { 2 - 4 } & NDWI & 10,88 & $\mathbf{9 9 , 3 5}$ \\
\hline \multirow{3}{*}{7.6 .2014}$. & B5 & 11,40 & $\mathbf{2 9 , 3 6}$ \\
\cline { 2 - 4 } & NDVI & 9,75 & 20,59 \\
\cline { 2 - 4 } & NDWI & 10,88 & 24,16 \\
\hline \multirow{3}{*}{13.10 .2014}$. & B5 & 11,40 & - \\
\cline { 2 - 4 } & NDVI & 9,75 & - \\
\cline { 2 - 4 } & NDWI & 10,88 & - \\
\hline
\end{tabular}


a)
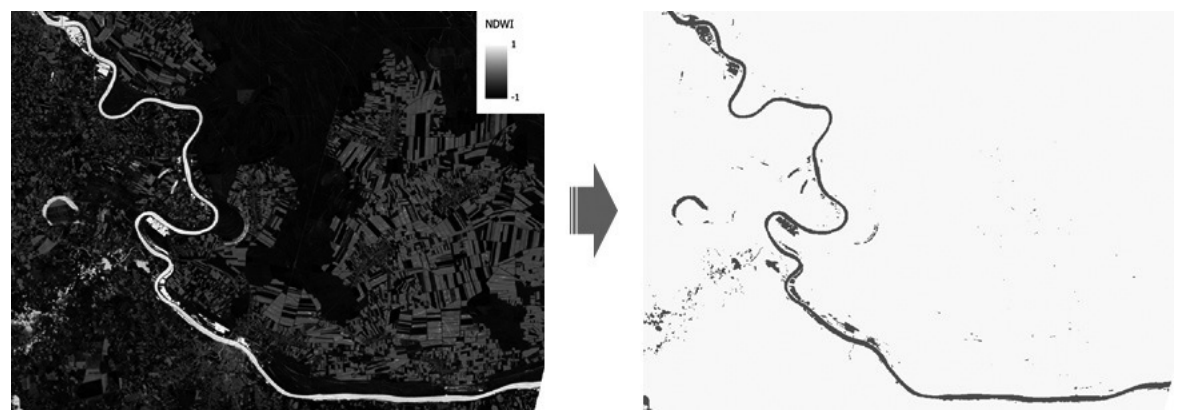

b)
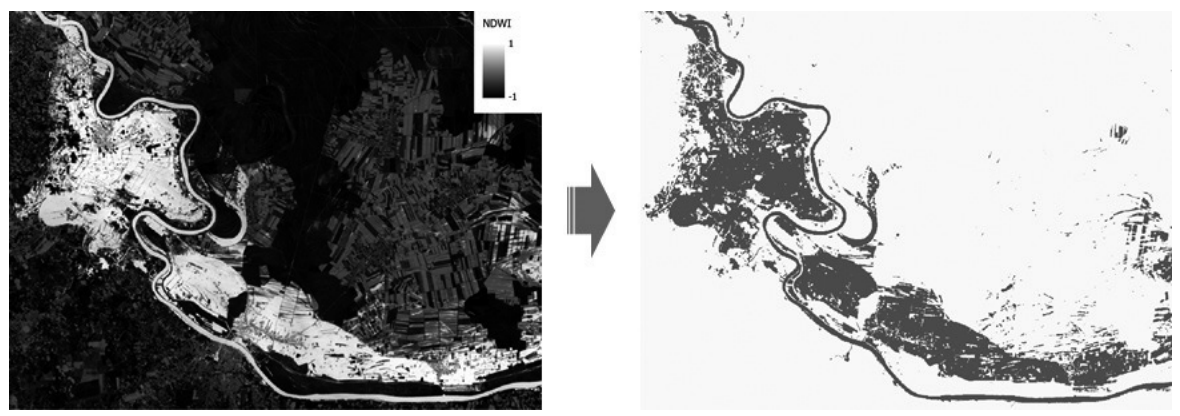

C)
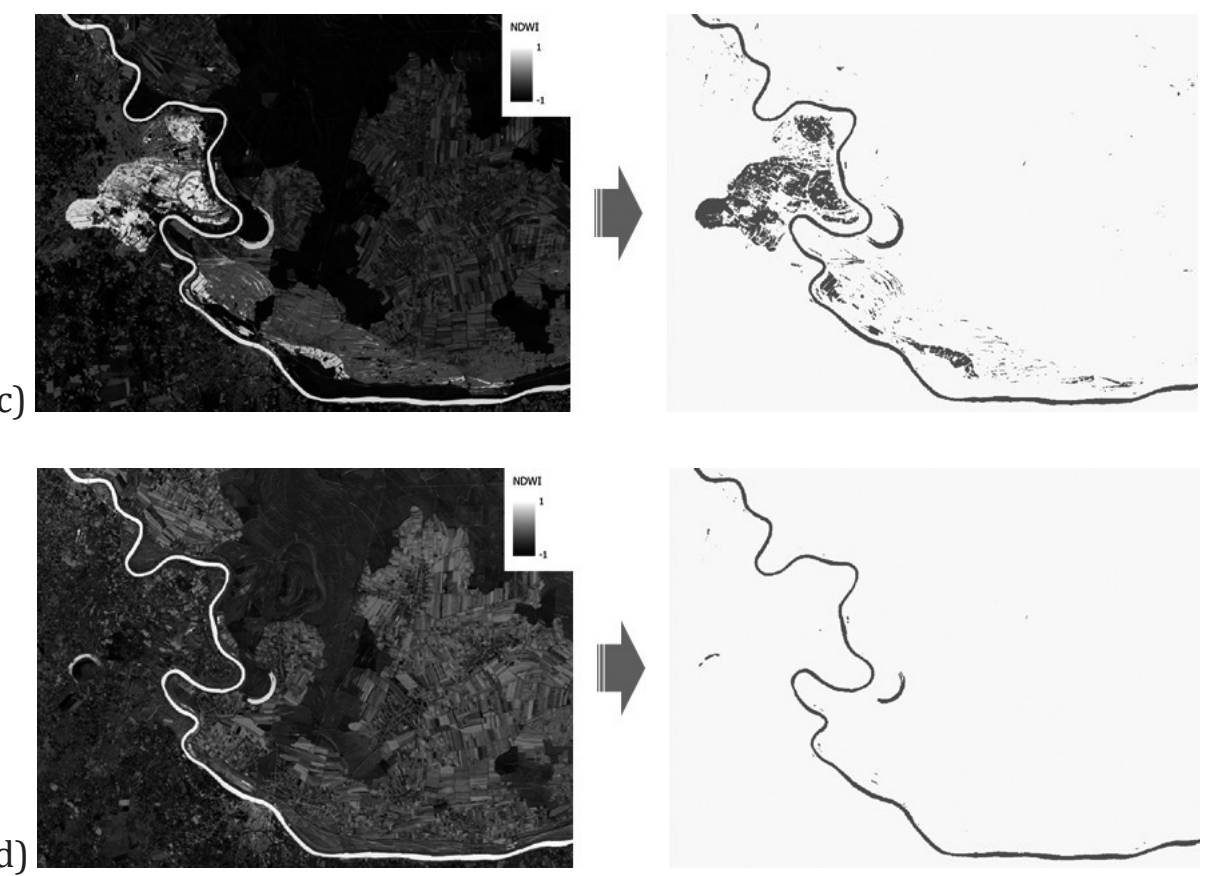

Slika 7. Klasifikacija indeksa NDWI: a) 6. svibnja 2014.; b) 22. svibnja 2014.; c) 7. lipnja 2014.; d) 13. listopada 2014. 
Maksimalna registrirana veličina poplavljene površine na dan 22. 5 . 2014. registrirana je metodom NDWI i iznosi $99,35 \mathrm{~km}^{2}$. Za datum prije poplave najveća površina prekrivena vodom izvan korita Save određena je pomoću NDVI-a i iznosila je $8,65 \mathrm{~km}^{2}$. Kad se poplavljena voda počela povlačiti, najveća je površina zabilježena klasifikacijom blisko IC kanala satelitske snimke, a iznosila je 29,36 $\mathrm{km}^{2}$. Razlog ovakvim razlikama u performansama metoda može se naći prvenstveno u subjektivnosti pristupa. Naime, jednokanalna metoda se temelji na vizualnoj analizi histograma odabranog kanala i subjektivnoj procjeni granice između vode i kopna (Slika 5). Iako se na svim histogramima jasno razaznaju dijelovi koji pripadaju vodenim i kopnenim pikselima u vidu dva izražena maksimuma, granica između tih dviju klasa je donekle nejasna pa će i najmanje odstupanje rezultirati različitom veličinom površina. Kod NDWI-a, kao što je već i navedeno, pojedine izgrađene površine mogu biti klasificirane kao vodene; vodene površine imaju vrlo nisku refleksiju u blisko IC dijelu spektra za razliku od kopnenih površina, posebno vegetacije koja reflektira i do $50 \%$ blisko IC valnih duljina (slika 3). NDWI naglašava tu razliku maksimalno uvećavajući utjecaj razlike refleksije vidljivih valnih duljina u zelenom dijelu spektra i niske refleksije blisko IC zračenja $s$ vodenih površina na vrijednost indeksa. Iako pozitivne vrijednosti indeksa upućuju na vodu, neke kopnene površine mogu imati veću refleksiju u zelenom dijelu spektra u odnosu na blisko IC, što će rezultirati pozitivnim vrijednostima indeksa. Kod NDVI-a je to i naglašenije budući da je razlika između refleksije u crvenom i blisko IC dijelu spektra manja (Slika 3) pa je mogućnost pogreške u klasifikaciji na vodene i kopnene površine veća nego kod NDWI-a.

Veliku ulogu u klasifikaciji na vodene i nevodene površine ima i prostorna rezolucija odabrane snimke. Prostorna rezolucija, odnosno veličina piksela Landsat 8 snimke je $30 \mathrm{~m}$. U graničnoj zoni između vode i kopna pikseli će sadržavati miješanu informaciju, a što je prostorna rezolucija manja, odnosno dimenzije piksela veće, veća je mogućnost pogreške u klasifikaciji na vodene i nevodene piksele. Nadalje, poplave sa sobom nose veliku količinu nanosa, a spektralne karakteristike nanosa razlikuju se od spektralnih karakteristika vode. Suspendirani nanos zamućuje vodu pa tako utječe na reflektivne karakteristike poplavne vode, posebno u blisko IC dijelu spektra, što će utjecati na točnost klasifikacije. Slično se događa kod voda s visokim sadržajem klorofila te kod onečišćenih voda. 


\section{Zaključak}

Na primjeru poplave iz svibnja 2014. godine prikazan je mogući pristup kartiranju poplavljene površine. Osim u kontekstu identifikacije i procjene opsega poplave, ovaj pristup ilustrira i praćenje dinamike same pojave kroz vremenski period od pet mjeseci. Podloga za analizu su bile Landsatovi snimke preuzete s USGS portala Earth Explorer (https://earthexplorer. usgs.gov/). Kako im je prostorna rezolucija $30 \mathrm{~m}$, odstupanja u definiranju opsega poplave zbog miješanih spektralnih karakteristika vode i kopna u graničnim pikselima su očekivana pa treba naglasiti da bi snimke visoke prostorne rezolucije dale precizniju procjenu granice između vode i kopna. To je posebno bitno kod procjene nastalih šteta radi kompenzacije materijalnih gubitaka stanovnicima pogođenih područja. Integracijom dobivene klasifikacije $\mathrm{s}$ terenskim podacima, odnosno usporedbom rezultata s informacijama dobivenim u kontaktu sa stanovnicima pogođenog područje moguće je jasnije ustvrditi razmjere poplave, a time i razmjere materijalne štete koju je ta poplava uzrokovala.

Daljinska istraživanja su unaprijedila proces kartiranja poplavljenih područja. Kvaliteta snimaka, brzina snimanja i kontinuirano snimanje zemljine površine sa svemirske ili zračne platforme omogućili su ažurno praćenje stanja poplavljenog područja. U usporedbi s konvencionalnim metodama kartiranja pojave, ovaj pristup omogućuje i snimanje teško pristupačnih ili nedostupnih površina, kao i velikih površina, što je velika prednost kada je riječ o kartiranju poplava. Visoka vremenska rezolucija, odnosno kratko vrijeme koje je potrebno da se ponovo snimi istraživana površina daje uvid i u dinamiku pojave. Iako je velika mana optičkih senzora nemogućnost prodiranja reflektiranog zračenja kroz naoblaku i maglu, što je čest slučaj u vrijeme poplava, jednako kao i nemogućnost prodiranja kroz gusti vegetacijski pokrov koji zakriva poplavljenu površinu (npr. gusta šuma), daljinska istraživanja su nezamjenjiv izvor informacija nužnih za kvalitetno upravljanje poplavama.

\section{Literatura}

[1] CRED (Centre for Research on the Epidemiology of Disasters). (2020) Natural Disasters 2019: Now is the Time to not Give Up. Brussels: CRED. https://www.emdat.be/natural-disasters-2019-now-time-not-give

[2] EASAC (Auropean Academies' Science Advisory Council). (2018) Extreme Weather Events in Europe: Preparing for CLimate Change Adaptation: An Update on EASAC's 2013 Study. Halle, Germany, EASAC. https://easac.eu/ fileadmin/PDF s/reports statements/Extreme Weather/EASAC Extreme Weather 2018 web.pdf 
[3] UNESCO (United Nations Educational, Scientific and Cultural Organization). (2021) The United Nations World Water Development Report 2021: Valuing Water. Paris: UNESCO.

[4] Blöschl, G., Hall, J., Parajka, J., Perdigão, R. A., Merz, B., Arheimer, B., Aronica, G. T., Bilibashi, A., Bonacci, O., Borga, M., Čanjevac, I., Castellarin, A., Chirico, G. B., Claps, P., Fiala, N., Gorbachova, L., Gül, A., Hannafor, J., Harrigan, S., Kireeva, M., Kiss, A., Kjeldsen, T. R., Kohnová, S., Koskela, J. J., Ledvinka, O., Macdonald, N., Mavrova-Guirguinova, M., Mediero, L., Merz, R., Molnar, P., Montanari, A., Murphy, C., Osuch, M., Ovcharuk, V., Radevski, I., Rogger, M., Salinas, J. L., Sauquet, E., Šraj, M., Szolgay, J., Viglione, A., Volpi, E., Wilson, D., Zaimi, K., Živković, N. (2017) Changing Climate Shifts Timing of European Floods. Science 357/6351, str. 588-590, doi: 10.1126/science.aan2506

[5] Horvat, B. (2014) Daljinska istraživanja u monitoringu poplava. Hrvatska vodoprivreda 22, 207, str. 113-115.

[6] Wang, Y. (2004) Using Landsat 7 TM Data Acquired Days after a Flood Event to Delineate the Maximum Flood Extent on a Coastal Floodplain. International Journal of Remote Sensing 25, 5, str. 959-974.

[7] DHMZ, „Ukupna mjesečna i godišnja količina oborine“, DHMZ (Državni hidrometeorološki zavod), 05 2014. [Online]. Available: https://meteo.hr/ klima.php?section=klima podaci\&param=k2 1\&Godina=2014.

[8] DHMZ, „Odstupanje količine oborine za svibanj 2014.", DHMZ (Državni hidrometeorološki zavod), 05 2014. [Online]. Available: http://meteo.hr/ klima.php?section=klima pracenje\&param=ocjena\&MjesecSezona=5\&Godi $\underline{\text { na }=2014}$.

[9] Kuspilić, N., Oskoruš, D., Vujnović, T. (2014) Jednostavna istina - rijedak hidrološki događaj. Građevinar 66, 7, 653-661.

[10] Vrančić, T. (2014): Katastrofalne poplave na istoku Hrvatske: Svi dosadašnji vodostaji nadmašeni za cijeli metar. Građevinar, 66, 10, 937-952

[11] USGS (U.S. Geological Survey). (2019) Landsat 8 (L8): Data Users Handbook. LSDS-1574, Version 5.0, Department of the Interior U.S. Geological Survey, Sioux Falls, South Dakota, USA.

[12] Horvat, B. (2014) Kartiranje poplavljene površine korištenjem optičkih satelitskih snimaka. Hrvatske vode, 22, 88, str. 166-171.

[13] Holme, A. M., Burnside, D. G. i Mitchell, A. A. (1987) The Developmnet of a System for Monitoring Trend in Range Condition in the Arid Shrublands of Western Australia. Australian Rangeland Journal, 9, str. 14-20.

[14] Lillesand, T. M. i Kiefer, R. W. (1994) Remote Sensing and Image Interpretation. John Wiley \& Sons, Inc.

[15] McFeeters, S. K. (1996) The Use of Normalized Difference Water Index (NDWI) in the Delineation of Open Water Features. International Journal of Remote Sensing, 17, str. 1425-1432.

[16] Xu, H. (2006) Modification of Normalised Difference Water Index (NDWI) to Enhance Open Water Features in Remotely Sensed Imagery. International Journal of Remote Sensing, 27, 14, str. 3025-3033. 